15 Little RJA, Rubin DB. Statistical Analysis with Missing Data. John Wiley \& Sons, 1987.

16 Thompson SG, Barber J. How should cost data in pragmatic randomised trials be analysed? BMJ 2000; 320: 1197-200.

17 Efron B, Tibshirani RJ. An Introduction to the Bootstrap. Chapman \& Hall, 1993.

18 Gureje O, Ustun TB, Simon GE. The syndrome of hypochondriasis: a crossnational study in primary care. Psychol Med 1997; 27: 1001-10.

19 Creed F, Barsky A. A systematic review of the epidemiology of somatisation disorder and hypochondriasis. J Psychosom Res 2004; 56: 391-408.

20 Sumathipala A, Siribaddana S, Abeysingha MRN, De Silva P, Dewey M, Prince $\mathrm{M}$, Mann AH. Cognitive-behavioural therapy $v$. structured care for medically unexplained symptoms: randomised controlled trial. Br J Psychiatry 2008; 193: 51-9.

21 Kroenke K, Swindle R. Cognitive-behavioral therapy for somatization and symptom syndromes: a critical review of controlled clinical trials. Psychother Psychosom 2000; 69: 205-15.

22 Bisson Jl, Ehlers A, Matthews R, Pilling S, Richards D, Turner S. Psychological treatments for chronic post-traumatic stress disorder: systematic review and meta-analysis. Br J Psychiatry 2007; 190: 97-104.
23 Tyrer P, Baldwin D. Generalised anxiety disorder. Lancet 2006; 368: 2156-66.

24 Hakkaart-Van Roijen L, Van Straten A, Al M, Rutten F, Donker M. Cost-utility of brief psychological treatment for depression and anxiety. Br J Psychiatry, 2006; 188: 323-9.

25 Kennedy TM, Chalder T, McCrone P, Darnley S, Knapp M, Jones RH, Wessely S. Cognitive behavioural therapy in addition to antispasmodic therapy for irritable bowel syndrome in primary care: randomised controlled trial. Health Technol Assess 2006; 10: 1-67.

26 Rode S, Salkovsis $\mathrm{P}$, Dowd $\mathrm{H}$, Hanna $\mathrm{M}$. Health anxiety in chronic pain clinic attenders. J Psychosom Res 2004; 60: 155-61.

27 Jones FA. The role of bibliotherapy in health anxiety: an experimental study. Br J Community Nurs 2002; 7: 498-504.

28 Kjaergard LL, Villumsen J, Gluud C. Reported methodologic quality and discrepancies between large and small randomized trials in meta-analyses. Ann Intern Med 2001; 135: 982-9.

29 Layard R. The case for psychological treatment centres. BMJ 2006; 332 1030-2.

30 Rief W, Sharpe M. Somatoform disorders - new approaches to classification, conceptualization, and treatment. J Psychosom Res 2004; 56: 387-90.

\section{Psychiatry in the} old Testament

\title{
Lost in translation: the biblical classification of personality disorder
}

\author{
George Stein
}

The Book of Proverbs gives advice on the best way to achieve a contented life and a high standard of personal morality. Those who can achieve this are called 'the wise' who are righteous, but those who cannot are 'the fools' who are wicked. Psychiatric interest lies in the description of the latter. Unfortunately, the single word 'fool' in the St James's version (as well as in all later editions) was used as the English translation for eight separate Hebrew words, each of which described a quite distinct character. In this way the elaborate ancient Hebrew character typology was effectively lost in translation.

The main types of Hebrew fool were: kesil (literally, stupid and over-confident), an unintelligent person frequently involved in quarrels; ewil, a morally blind individual, but more intelligent than kesil; pethi, a simpleton, perhaps with intellectual disability, who cannot plan for the future; the hasar-leb (literally, empty-hearted), also of poor intelligence, who neglects himself and his property. Other characters are also occasionally mentioned: ba-ar, a crude individual; nabal, a brutal and depraved man (the word nabal also means wine skin suggesting a link with alcoholism); holel, an irrational madman; les, also translated as a scoffer, was a contemptuous narcissistic individual while belial (a scoundrel) was an aggressive psychopath who shows most of the features of DSM-IV antisocial personality disorder. Finally, a female character essa zarah, the strange woman or loose woman, a loud, rebellious person, constantly on the go, has numerous affairs and shows both borderline and histrionic features.

A much more detailed description and analysis of each of these character types, some of whom resemble DSM-IV personality disorder types, is given by Fox (Proverbs 1-9. The Anchor Bible, vol. 18A; Doubleday, 2000), who wrote that the fools of the Book of Proverbs were 'aberrant individuals, just stupid folk who [caused] harm above all to themselves and whose punishment [was] inevitable'. This definition will seem familiar to most psychiatrists who work with people with personality disorders. It is also not too far from Schneider's original definition (in his 1923 title Die Psychopathischen Personlichkeiten) of an individual with a personality disorder as 'a person who suffers or makes others suffer because of his abnormal personality'. The Book of Proverbs and its character typology was written more than 2500 years ago. 